\title{
МЕТОДИ ОЦІНКИ ПРОФЕСІЙНО ВАЖЛИВИХ ЯКОСТЕЙ ТА КОМПЕТЕНЦЙ ПРАЦІВНИКІВ СЛУЖБИ ЦЕНТРУ ЕКСТРЕНОЇ МЕДИЧНОЇ ДОПОМОГИ ТА МЕДЕЦИНИ КАТАСТРОФ
}

\author{
УДК:159.9.072.42
}

\section{Удод Максим Олександрович}

Аспірант денної форми навчання Інституту психології імені Г.С Костюка НАПН Украӥни, м. Київ (Украӥна)

\begin{abstract}
Анотація. Встановлено, що в практиці психології управління людськими ресурсами представлене велике розмаӥття методів оцінки професійно важливих якостей та компетенцій, а саме методи спостереження, інтерв'ю, психодіагностичні та біографічні методи, метод асесмент-цุентру. Для оцінки професійно важливих якостей та компетенцій працівників служби центру екстреної медичної допомоги та медицини катастроф (ЦЕМД та МК) доцільно застосовувати методи експертної оцінки, структурованого інтерв'ю та психодіагностичні методи. Психодіагностичні методи представляють особливий науковий інтерес, оскільки дозволять побачити зв'язки між діагностичними параметрами та реальною успішністю працівників служби ЦЕМД та МК в процесі виконання ними професійної діяльності. Оскільки психологічні характеристики людини на емоційно-вольовому та мотиваційно-ціннісному рівнях менш піддаються змінам в процесі діяльності, ніж характеристики ї̈ кваліфікації, знання, вміння i навички, вони в першу чергу представляють інтерес при здійсненні професійного відбору прачівників служби ЦЕМД та МК.
\end{abstract}

Ключові слова: професійно важливі якості, компетениії, компетентність, спостереження, інтерв'ю, психодіагностичні та біографічні методи, метод асесмент-иентру.

Постановка проблеми. Сучасна система професійної орієнтації та управління людськими ресурсами передбачає використання компетентнісного підходу, а поняття компетентності чи компетенції для опису знань і вмінь, які необхідні фахівцю для ефективного виконання його професійних обов'язків. В сфері професійної діяльності поняття компетентності запропоноване $\mathrm{P}$.
Бояцисом для позначення здатності людини поводитись у такий спосіб, який задовільняє вимогам роботи в певному організаційному середовищі, що дає можливість досягати бажаних результатів [3].

Розвиток професійно важливих якостей фахівця $\epsilon$ необхідною умовою успішного здійснення професійної діяльності в сучасних умовах, які передбачають піi постійні зміни та 
ускладнення, a тому кидають виклик та дозволяють професіоналу реалізовувати та розгортати свої професійні компетентності та особистісні ресурси у всій повноті в процесі цього здійснення. У психологічних дослідженнях показано, що співвідношення особистісного та професійного розвитку має нерівноважну цілісність, яка виражається в тому, що на початкових етапах професійного розвитку його джерелом $\epsilon$ рівень особистісного розвитку, а потім, на подальших стадіях, професійний розвиток починає домінувати над особистісним [13].

Вихідні передумови. В рамках проблемно-орієнтованого підходу (Дж. Вос, Г. Драйден [5], О. І. Пометун [7], Дж. Равен [9]) компетентність визначається як рівень успішності розв'язання проблемних ситуацій під час виконання професійної діяльності, що передбачає поєднання орієнтувальних та виконавчих компонентів. Функціональнодіяльнісний підхід (B. А. Семиченко [12]) розглядає компетентність як готовність до виконання професійних функцій, що вимагає аналітичних, прогностичних, проективних, рефлексивних, організаторських, комунікативних вмінь. В. І. Байденко [2] визначає компетентність через готовність та здатність цілеспрямовано діяти відносно до вимог справи, методично організовано та самостійно вирішувати завдання і проблеми, самостійно оцінювати результати своєї діяльності. Професійну компетентність працівника служби ЦЕМД та МК можна визначити як особистісно та інтелектуально обумовлений досвід успішної соціальнопрофесійної діяльності, що базується на знаннях, вміннях і навичках.

В нашому дослідженні ми будемо спиратись на розуміння компетентності як сукупності професійно важливих якостей, які забезпечують здатність фахівця вирішувати завдання професійної діяльності: ставити ціль професійної діяльності, бачити проблему, визначати шляхи іiі вирішення, співвідносити вимоги ситуації та наявні можливості вирішення, шукати необхідні для вирішення проблеми ресурси. Задачу професійного відбору працівників служб екстреної медичної допомоги та медицини катастроф неможливо вирішити без підбору адекватного психодіагностичного методичного інструментарію, який дозволяє здійснювати комплексну, надійну та валідну оцінку професійно важливих якостей та компетенцій працівників. Підбір таких методів потребує ідентифікації значимих предикторів професійної успішності.

Мета статті - розглянути та класифікувати методи, скеровані на оцінку професійно важливих якостей працівників служб екстреної медичної допомоги та медицини катастроф.

Виклад результатів теоретичного дослідження. Серед предикторів професійної успішності працівників служб екстреної 
медичної допомоги $\epsilon$ як жорсткі фактори (hard skills - професійна підготовка та атестаційні оцінки), професійний досвід (стаж роботи, функції, рекомендації з попередніх місць роботи), біологічні ознаки (стать, вік, сімейний стан), так і м'які фактори (soft skills) - когнітивні, соціальні та особистісні компетенції [6]. Методи, які використовуються для оцінки професійно важливих якостей мають бути об'єктивними, надійними (отримання подібних результатів при повторному вимірюванні) і валідними (такими, що успішно прогнозують професійну ефективність працівника). Для оцінки прогностичної валідності методів використовується кореляційний аналіз між показниками, отриманими за допомогою діагностичного метода i вимірюваними показниками професійної ефективності працівника. У наукових працях зазначається, що прогностична валідність формальних даних, що оцінюють жорсткі фактори $€$ невеликою i має значення на етапі попереднього відбору персоналу як підготовка до співбесіди [6].

Застосування психодіагностичних опитувальників не завжди дає можливість отримати інформацію про професійно важливі якості, яка прямо співвідноситься 3 реальною здатністю працівника успішно виконувати трудові задачі, коли дані про зв'язок показників тестових шкал та особливості поведінки відсутні або їх кількість надто велика, щоб робити 3 цього конкретні висновки щодо професійної придатності. Перевірка прогностичної валідності особистісних опитувальників та проективних методик $є$ актуальною проблемою, оскільки такі методи розроблялись для потреб клінічної практики і зв'язок їх параметрів із професійною успішністю потребує додаткових досліджень. Валідність тестових методик, призначених для оцінки рівня інтелекту та тестів успішності (досягнень) зростає при їх тематичному наближенні до розв'язання реальних проблемних професійних ситуацій [6].

Застосування L-даних, які передбачають експертну, або групову оцінку особистості, що $є$ достатньо надійною, оскільки передбачає формалізацію оцінок експертів, які спостерігали за поведінкою фахівця в певних ситуаціях протягом деякого періоду часу, широко розповсюджене в практиці психології управління людськими ресурсами. Такі оцінки, які формуються в процесі спільного виконання професійно важливих задач дозволяють зафіксувати найбільш важливі, безпосередньо значимі для такого виконання професійні та особистісні якості [6;8].

Для оцінки великої групи людей використовується метод безпосередньої оцінки, що дозволяє порівняти між собою різних осіб за мірою вираженості якостей. Для забезпечення валідності і надійності оцінок 
необхідно призначити групу кваліфікованих експертів, які добре знають фахівця, якого оцінюють та мають відносно нього певну посадову позицію, наприклад, керівник, два підлеглих, два працівника 3 аналогічною посадою, при цьому вони всі повинні мати безпосередні професійні контакти 3 оцінюваним фахівцем. Для підвищення достовірності оцінок зберігається їх анонімність, результати представляють тільки в усередненому для групи експертів вигляді [6; 8]. Для забезпечення надійності даних та отримання необхідного рівня дискримінативності (значимих відмінностей між успішними та неуспішними кандидатами) необхідно чітко визначити математичну модель оцінювання. Якщо внесок оцінюваних професійно важливих якостей $€$ різним, необхідно використовувати вагові коефіцієнти, які відображають міру впливу конкретного показника на загальний результат [8].

Середню прогностичну валідність мають біографічні методи, які розгорнуто виявляють установки, мотиви і попередній життєвий досвід особистості [6].

Найвищою прогностичною валідністю характеризується метод симуляції в роботі асесмент-центру, коли для працівників 3 максимальною наближеністю до реальності створюються ситуації 3 організаційноспецифічними вимогами i конкретним переліком завдань, за виконанням яких спостерігають одночасно декілька експертів, які оцінюють працівників за заздалегідь визначеними критеріями. Експерти мають бути незалежними та пройти попередню інтенсивну підготовку до здійснення процедур спостереження і оцінки, а також управління самою процедурою. Типові вправи, які використовуються в роботі асесмент-центрів це поштові скрині, групові дискусії, рольові ігри, кейс-метод, презентації, структуровані інтерв’ю, які треба попередньо розробити [6; 8]. Такий метод передбачає значні методичні та внутрішньоорганізаційні витрати і ставить перед керівництвом організації етичні проблеми, оскільки орієнтований на конкуренцію, в той час як в інтересах будьякої організації передусім $\epsilon$ багатофункціональне співробітництво [6].

Ефективною альтернативою $\epsilon$ метод структурованого інтерв'ю, який дає можливість вступити в контакт, безпосередньо задати питання працівнику та скласти думку про нього [6; 8]. Структурування інтерв'ю відбувається на трьох рівнях: структурування змісту (створення профілю вимог та питань, які його відображають, стандартизація через створення керівництва для проведення інтерв'ю, адаптація форм і технік постановки запитань, визначення часових рамок, опрацювання додаткової інформації про працівника, відповіді на запитання працівника), структурування роботи інтерв'юєра (ведення 
записів, участь декількох інтерв'юєрів, інтенсивна підготовка інтерв'юєрів), структурування процесу оцінювання результатів інтерв'ю (оцінка відповідей i критеріїв вимог, використання оціночних шкал). Використовуються такі системи структурованого інтерв'ю як інтерв'ю - описи поведінки (питання про поведінку в минулому, що $\epsilon$ значимою відповідно до вимог), ситуативні інтерв'ю (питання про гіпотетичну поведінку в майбутньому) та інтегровані системи інтерв'ю (питання про минулу і майбутню поведінку, робочі проби, питання про знання). За В. Йєттером [6], в перелік якостей, які доцільно оцінювати протягом структурованого інтерв'ю входять вміння слухати, мовні здібності, письмове мовлення, реалізація спеціальної інформації, вміння працювати в команді, трудова мотивація, мотивація досягнення, ініціативність, стійкість до навантажень, витримка, надійність, лояльність до організації та етика, готовність навчатися, гнучкість, самостійність, стійкість до фрустрації, самопрезентація, емпатійність, контактність, вміння впливати на людей та вести переговори, стратегії поведінки в конфлікті, здатність до співпраці, управління та лідерський потенціал, здатність аналізувати та оцінювати проблемні ситуації, готовність приймати рішення, креативність, спеціальні знання, планування та організація діяльності. Результати досліджень показали, що працівники, які були підібрані за допомогою структурованого інтерв'ю, на 45\% рідше звільнялись з роботи і отримали вищі оцінки продуктивності ніж ті, кого підбирали методом традиційного інтерв'ю [6, с.147].

Отже, для виявлення професійно важливих якостей та компетенцій та здійснення психологічного відбору працівників служби ЕМД та МК доцільно використовувати сполучення методів експертної оцінки, психологічної діагностики та структурованого інтерв'ю.

У дослідженнях різних авторів
(3. О. Алборова
[1],
Г. Ю. Сагдулліна,

Р. Ю. Самігуллін

[10],

C. В. Сехін,

T. В. Павлюченкова [13], М. М. Філоненко [14], М. Б. Чижкова [15]) до професійно важливих якостей медичного працівника відносять емоційно-вольові (здатність брати на собі відповідальність в складних ситуаціях, високий самоконтроль емоцій та поведінки, емоційна стійкість, врівноваженість, збереження зібраності в умовах, стимулюючих збудження, здатність до швидкої мобілізації зусиль), комунікативні (швидко встановлювати контакт 3 новими людьми, викликати прихильність і довіру людей, знаходити потрібний тон, доцільну форму спілкування 3 пацієнтами, здатність передавати іншим людям позитивний емоційний заряд, дотримання етичних та деонтологічних норм, уміння погоджувати свої дії 3 діями інших осіб, володіння 
іноземними мовами), якості i властивості працездатності (швидко входити в робочий процес i збільшувати працездатність на завершальних етапах роботи, здатність до ефективного планування своєї діяльності, витривалість, стійкість до перешкод, ефективність праці в умовах поєднання тривалих інтервалів праці і відпочинку, збереження високої працездатності в умовах монотонії), мнемічні (готовність до швидкого запам'ятовування та оперативного використання наявного в пам'яті матеріалу, здатність утримувати в пам'яті велику кількість матеріалу, точно відтворювати раніше засвоєну інформацію i використовувати ऑii на практиці), атенційні (тривалий час зберігати стійку увагу, незважаючи на втому та сторонні подразники, розподіляти увагу при виконанні декількох дій, функцій, завдань, довільно керувати увагою та зберігати необхідну концентрацію в умовах монотонії, великий об'єм мимовільної та післядовільної уваги), мисленнєві (вміння приймати правильне рішення при відсутності або браку необхідної інформації або відсутності часу на ii осмислення, робити висновки 3 суперечливих даних, критично аналізувати інформацію, оперувати нею, бачити дальше безпосередньо даного i очевидного, розпізнавати проблемну ситуацію, там, де нібито все вирішено), мовні (уміння грамотно, зв'язно i логічно формулювати свої думки в розгорнутій формі) та імажинативні властивості (здатність знаходити нові i незвичайні рішення, прогнозувати результат подій з урахуванням їх вірогідності; бачити декілька можливих шляхів i подумки вибирати найбільш ефективний). Також важливими якостями є моторні (стійкість до статичних навантажень, добра координація рухів, швидка реакція на раптові подразники за допомогою певних рухів; швидкість і точність дрібної моторики), оптимізм та позитивна життева спрямованість, спостережливість та інтерес до внутрішнього світу людини, високий поріг гидливості та відсутність комунікативних бар’єрів. Цікаво також, що наприклад, лікарі iз стажем на перше місце поставили високе почуття відповідальності, інтерни - розвинуте аналітичне мислення, студенти - високу концентрацію уваги [10, с.101].

Опитування працівників служби екстреної медичної допомоги та медицини катастроф станцій різних районів м. Києва (n=141) показало, що до найбільш значимих ними були віднесені такі якості, як емоційновольові якості $(87,2 \%), \quad$ властивості працездатності $\quad(85,6 \%), \quad$ професійну обізнаність $(84,1 \%)$, комунікативні $(81,3 \%)$, мисленнєві якості $(80,4 \%)$, та особливості мотивації (78,3\%). Ці характеристики, співвіднесені 3 континуально-ієрархічною структурою особистості О. П. Саннікової [11] та аксіологічним проектом професійноособистісного становлення працівника сфери 


\begin{tabular}{|c|c|c|}
\hline Рівень & $\begin{array}{c}\text { Професійно значимі якос- } \\
\text { ті / компетенції }\end{array}$ & Діагностичні інструменти \\
\hline $\begin{array}{l}\text { Засновані на парамет- } \\
\text { рах особистості: емо- } \\
\text { ційно-вольовий рівень } \\
\text { Нейротизм, екстравер- } \\
\text { тованість, координація, } \\
\text { реактивність, швидкість } \\
\text { реакцій, витривалість, } \\
\text { стійкість до стресів, ада- } \\
\text { птаційний потенціал }\end{array}$ & $\begin{array}{c}\text { Здатність до збереження та } \\
\text { відновлення емоційної рів- } \\
\text { новаги, працездатності в } \\
\text { стресових умовах, здатність } \\
\text { мобілізувати ресурси орга- } \\
\text { нізму, здійснювати емоцій- } \\
\text { ну саморегуляцію }\end{array}$ & $\begin{array}{c}\text { Копінг-стратегії (С.Хобфолл, } \\
\text { Р.Лазарус, Е.Хейм) } \\
\text { Соціально-психологічна адаптова- } \\
\text { ність (О.П.Саннікова) } \\
\text { Структура темпераменту (В.Русалов) } \\
\text { Сігналетичний опитувальник } \\
\text { Оцінка емоційного стану } \\
\text { (А.Уессман, Д.Рікс) } \\
\text { Оцінка невротизації } \\
\text { Оцінка стресостійкості (Бостонський } \\
\text { тест, С.Коухен, Г.Вілліансон) }\end{array}$ \\
\hline $\begin{array}{l}\text { Засновані на виконан- } \\
\text { ні завдань та діяльнос- } \\
\text { ті: мотиваційно- } \\
\text { ціннісний рівень } \\
\text { Професійна спрямова- } \\
\text { ність, установки, моти- } \\
\text { ви. Соціально- } \\
\text { комунікативні здібності }\end{array}$ & $\begin{array}{c}\text { Відкритість та гнучкість } \\
\text { мислення і практичної дії, } \\
\text { особистісна автономія та } \\
\text { зрілість, соціальна компете- } \\
\text { нтність, свобода вибору та } \\
\text { відповідальність за його } \\
\text { наслідки }\end{array}$ & $\begin{array}{c}\text { Задоволеність роботою } \\
\text { (привабливість праці) } \\
\text { Якорі кар'єри (Е.Шейн) } \\
\text { Мотиви вибору професії } \\
\text { (Р.Овчарова, Е.Павлютенков) } \\
\text { Емоційний інтелект (Н.Холл, } \\
\text { Д.Люсін) } \\
\text { Комунікативні та організаторські зді- } \\
\text { бності (КОС) } \\
\text { Гіссенський особистісний опитуваль- } \\
\text { ник } \\
\end{array}$ \\
\hline $\begin{array}{l}\text { Засновані на управлін- } \\
\text { ні результатами діяль- } \\
\text { ності: рефлексивно- } \\
\text { діяльнісний рівень } \\
\text { Професійна компетент- } \\
\text { ність, професійні знан- } \\
\text { ня, уміння і навички, } \\
\text { кваліфікація. Спеціаль- } \\
\text { на і } \\
\text { персональна компетент- } \\
\text { ність, аутокомпетент- } \\
\text { ність }\end{array}$ & $\begin{array}{c}\text { Засвоєння конкретних соці- } \\
\text { ально-професійних вмінь, } \\
\text { розвиток поведінкових та } \\
\text { рефлексивних здібностей } \\
\text { професіонала, накопичення } \\
\text { та переробка власного про- } \\
\text { фесійного досвіду та про- } \\
\text { фесійне зростання }\end{array}$ & $\begin{array}{c}\text { Короткий орієнтувальний тест } \\
\text { (В.Бузін, Е.Вандерлік) } \\
\text { Когнітивно-діяльнісний стиль } \\
\text { (Л.Ребекка) } \\
\text { Стиль саморегуляції поведінки } \\
\text { (В.Моросанова, В.Звєрьков, } \\
\text { С.Ейдман) } \\
\text { Опитувальник самоорганізації діяль- } \\
\text { ності } \\
\text { Експертна оцінка керівництва, спо- } \\
\text { стереження, структуроване інтерв’ю }\end{array}$ \\
\hline
\end{tabular}

\section{«людина-людина» I. М. Грицюк [4], були} покладені в основу вибору методів оцінки професійно важливих якостей та компетенцій працівників служби ЕМД та стали орієнтиром для вибору релевантних методів оцінки професійно важливих якостей та компетенцій працівників служби екстреної медичної допомоги та медицини катастроф (таблиця 1).

В першу чергу при цьому слід звертати увагу на якості, які не підлягають тренажу i вправлянню, тобто, пов'язані із стійкими властивостями нервової системи або $\epsilon$ 
ригідними внаслідок інших чинників, наприклад, мотиваційно-ціннісні утворення. Отже, найбільшу увагу в процесі професійного відбору слід приділити першим двом рівням (таблиця 1), тоді як третій рівень є більш пластичним утворенням: кваліфікація працівника, знання, вміння і навички постійно зростають із набуттям реального професійного досвіду, якщо працівник $\epsilon$ психологічно придатний та достатньо мотивований для ефективного здійснення професійної діяльності.

Висновки та перспективи подальших досліджень. В управлінні людськими ресурсами в галузі екстреної медичної допомоги та медицини катастроф, зокрема, 3 метою професійного відбору, слід користуватися різними методами діагностики професійно значимих якостей та компетенцій, серед яких найбільш доцільно використовувати методи експертної оцінки, структурованого інтерв'ю та психодіагностичні методи. Використання психодіагностичних методів у комплексі 3 параметрами реальної професійної діяльності суб'єкта праці дозволить встановити відповідності між особистісними характеристиками (емоційними, вольовими, когнітивними, комунікативними, мотиваційними) та успішністю професійної діяльності працівників служби екстреної медичної допомоги та медицини катастроф.

\section{Перелік використаних джерел:}

1. Алборова 3. О. Профессионально важные качества (ПВК) в структуре субъектных свойств врача // СИСП. 2012. №7. URL: http://cyberleninka.ru/article/n/ professionalno-vazhnye-kachestva-pvk-v-strukturesubektnyh-svoystv-vracha (дата звернення: 28.02.2017).

2. Байденко В. И. Компетентностный подход к проектированию государственных образовательных стандартов высшего профессионального образования (методологические и методические вопросы): методическое пособие / В.И.Байденко. - М.: Исследовательский центр проблем качества подготовки специалистов, 2005. - 114 с.

3. Бояциис $P$. Компетентный менеджер. Модель эффективной работы [Текст] / Ричард Бояцис; пер с англ. - М.: ГИППО, 2008. - 352 с.

4. Грицююк I. M. Соціальні орієнтації фахівців соціономічних професій: теорія, практика, методи вивчення /І.М.Грицюк. - Луцьк: Вежа-Друк, 2015. - 188 c.

5. Драйден Г. Революция в обучении. Научить мир учиться по новому / Г.Драйден, Дж.Вос. - М.: ПРАВИНЭ, 2003. - 672 c.

6. Йеттер В. Эффективный отбор персонала. Метод структурированного интервью / В.Йеттер. - Х.: Изд-во «Гуманитарный центр», 2011. - 360 с.

7. Пометун $O . \quad$ I. Теорія та практика послідовної реалізації компетентнісного підходу в досвіді зарубіжних країн / О.І.Пометун. - К.: К.I.C., 2004.-C.16 $-26$.

8. Практикум по психологии менеджмента и профессиональной деятельности

под.ред.Г.С.Никифорова, М.А.Дмитриевой, В.М.Снеткова. - СПб.: Речь, 2001. - 448 с.

9. Равен Дж. Компетентность в современном обществе: выявление, развитие, реализация /Дж. Равен. - М. : Когито-Центр, 2002. - 396 с.

10. Сагдуллина Г. Ю., Самигуллин Р. Ю. Качественный 
анализ профессионально важных качеств врачей специальности лечебное дело // Международный журнал экспериментального образования. 2014. №6-1. URL: http://cyberleninka.ru/article/n/kachestvennyy-analizprofessionalno-vazhnyh-kachestv-vrachey-spetsialnostilechebnoe-delo (дата звернення: 28.02.2017).

11. Саннікова О. П. Досвід побудови моделі структури особистості професіонала / О.П.Саннікова. Проблеми розвитку педагогіки вищої школи в XXI столітті: теорія i практика // Матеріали Всеукраїнської науковопрактичної конференції (30-31 травня 2002p.) - Одеса, 2002. - Част. II. - С. 3-7.

12. Семиченко B. $A$. Пріоритети професійної підготовки: діяльнісний чи особистісний підхід? / В.А.Семиченко // Неперервна професійна освіта: проблеми, пошуки, перспективи.- К.: ВІПОЛ, 2000.C.176-203.

13. Сехин С. В., Павлюченкова Т. В., Никифоровский Н. К., Отвагина Н. М., Покусаева В. Н. Диагностика личностных компетенций студентов и выпускников высшей медицинской школы // Смоленский медицинский альманах. 2015. №2. URL: http:// cyberleninka.ru/article/n/diagnostika-lichnostnyhkompetentsiy-studentov-i-vypusknikov-vyssheymeditsinskoy-shkoly (дата звернення: 28.02.2017).

14. Філоненко M. M. Дослідження взаємозв'язку ефективності професійної підготовки майбутнього лікаря та формованості його особистісних структур URL: http://psytir.org.ua/upload/journals/8/authors/2015/ Filonenko_Myroslava_Myroslavivna_doslidzhennya_vzaje mozvyazku_efektyvnosti_profesijnoi_pidgotovky_maibutn ogo_likarya_ta_formovanosti_yogo_osobystisnyh_struktur. $\operatorname{pdf}$ (дата звернення: 28.02.2017).

15. Чижкова М. Б. Мотивы выбора профессии врача и их взаимосвязь с профессионально-значимыми качествами медицинского работника у студентовпервокурсников медицинского вуза // Современные проблемы науки и образования. 2015. №2. URL: http:// cyberleninka.ru/article/n/motivy-vybora-professii-vracha-i- ih-vzaimosvyaz-s-professionalno-znachimymi-kachestvami -meditsinskogo-rabotnika-u-studentov (дата звернення: 28.02.2017).

\section{References (Transliteration):}

1. Alborova Z. O. Professional'no vazhnye kachestva (PVK) v strukture subektnyh svojstv vracha // SISP. 2012. №7. URL: $\quad$ http://cyberleninka.ru/article/n/professionalnovazhnye-kachestva-pvk-v-strukture-subektnyh-svoystvvracha (data zvernennja: 28.02.2017).

2. Bajdenko $V$. I. Kompetentnostnyj podhod $\mathrm{k}$ proektirovaniju gosudarstvennyh obrazovatel'nyh standartov vysshego professional'nogo obrazovanija (metodologicheskie i metodicheskie voprosy): metodicheskoe posobie / V.I.Bajdenko. - M.: Issledovatel'skij centr problem kachestva podgotovki specialistov, 2005. - $114 \mathrm{~s}$.

3. Bojacis R. Kompetentnyj menedzher. Model' jeffektivnoj raboty [Tekst] / Richard Bojacis; per s angl. - M.: GIPPO, 2008. - 352 s.

4. Gricjuk I. M. Social'ni orientaciï fahivciv socionomichnih profesij: teorija, praktika, metodi vivchennja /I.M.Gricjuk. - Luc'k: Vezha-Druk, 2015. - 188 $\mathrm{S}$.

5. Drajden G. Revoljucija v obuchenii. Nauchit mir uchit'sja po novomu / G.Drajden, Dzh.Vos. - M.: PRAVINJe, 2003. - $672 \mathrm{~s}$.

6. Jetter $V$. Jeffektivnyj otbor personala. Metod strukturirovannogo interv'ju / V.Jetter. - H.: Izd-vo «Gumanitarnyj centr», 2011. - $360 \mathrm{~s}$.

7. Pometun O. I. Teorija ta praktika poslidovnoï realizaciï kompetentnisnogo pidhodu $\mathrm{v}$ dosvidi zarubizhnih kraïn / O.I.Pometun. - K.: K.I.S., 2004.-S.16-26.

8. Praktikum po psihologii menedzhmenta i professional'noj dejatel'nosti / pod.red.G.S.Nikiforova, M.A.Dmitrievoj, V.M.Snetkova. - SPb.: Rech', 2001. - 448 $\mathrm{s}$.

9. Raven Dzh. Kompetentnost' v sovremennom obshhestve: 
vyjavlenie, razvitie, realizacija /Dzh. Raven. - M. : KogitoCentr, 2002. - $396 \mathrm{~s}$.

10. Sagdullina G. Ju., Samigullin R. Ju. Kachestvennyj analiz professional'no vazhnyh kachestv vrachej special'nosti lechebnoe delo // Mezhdunarodnyj zhurnal jeksperimental'nogo obrazovanija. 2014. №6-1. URL: http:/cyberleninka.ru/article/n/kachestvennyy-analizprofessionalno-vazhnyh-kachestv-vrachey-spetsialnostilechebnoe-delo (data zvernennja: 28.02.2017).

11. Sannikova $O$. P. Dosvid pobudovi modeli strukturi osobistosti profesionala / O.P.Sannikova. Problemi rozvitku pedagogiki vishhoï shkoli v HHI stolitti: teorija i praktika // Materiali Vseukraïns'koï naukovo-praktichnoï konferenciï (30-31 travnja 2002r.) - Odesa, 2002. - Chast. II. - S. 3-7.

12. Semichenko $V$. A. Prioriteti profesijnoï pidgotovki: dijal'nisnij chi osobistisnij pidhid? / V.A.Semichenko // Neperervna profesijna osvita: problemi, poshuki, perspektivi.- K.: VIPOL, 2000.-S.176-203.

13. Sehin S. V., Pavljuchenkova T. V., Nikiforovskij N. K., Otvagina N. M., Pokusaeva V. N. Diagnostika lichnostnyh kompetencij studentov i vypusknikov vysshej medicinskoj shkoly // Smolenskij medicinskij al'manah. 2015. №2. URL: http:// cyberleninka.ru/article/n/diagnostika-lichnostnyh-

kompetentsiy-studentov-i-vypusknikov-vyssheymeditsinskoy-shkoly (data zvernennja: 28.02.2017).

13. Filonenko M. M. Doslidzhennja vzaєmozv'jazku efektivnosti profesijnoï pidgotovki majbutn'ogo likarja ta formovanosti jogo osobistisnih struktur URL: http:// psytir.org.ua/upload/journals/8/authors/2015/

Filonenko_Myroslava_Myroslavivna_doslidzhennya_vzaje mozvyazku_efektyvnosti_profesijnoi_pidgotovky_maibutn ogo_likarya_ta_formovanosti_yogo_osobystisnyh_struktur. pdf (data zvernennja: 28.02.2017).

14. Chizhkova M. B. Motivy vybora professii vracha i ih vzaimosvjaz' s professional'no-znachimymi kachestvami medicinskogo rabotnika u studentov-pervokursnikov medicinskogo vuza // Sovremennye problemy nauki i obrazovanija. 2015. №2. URL: http://cyberleninka.ru/ article/n/motivy-vybora-professii-vracha-i-ih-vzaimosvyaz- s-professionalno-znachimymi-kachestvami-meditsinskogorabotnika-u-studentov (data zvernennja: 28.02.2017).

\section{Udod Maxim}

PhD student at the G. S. Kostiyk Institute of psychology of the National Academy of Pedagogical sciences of Ukraine, Kyiv (Ukraine)

\section{METHODS OF ESTIMATION OF PROFESSIONALLY IMPORTANT INTERNALS AND COMPETENCES OF URGENT MEDICARE AND MEDICINE OF CATASTROPHES SERVICE WORKERS}

\section{ABSTRACT}

The modern system of labour organization, professional orientation and HRmanagement foresees the use of competency approach, and a concept of competence or competenses for description of knowledge and abilities that are in need for the effective implementation of professional duties by worker. The professional competence of urgent medicare and medicine of catastrophes service workers can be defined as the experience of successful social and professional activity, that is based on knowledge, abilities and skills. In practice of HRmanagement the large variety of estimation methods is presented for professionally important internalss and competenses, namely methods of supervision, interview, psychodiagnostic and biographic methods, assessment-center method. For an estimation of professionally important internalss and competenses of urgent medicare 
and medicine of catastrophes service workers it is expedient to apply the methods of expert estimation, structured interview and psychodiagnostic methods. Psychodiagnostic methods present the special scientific interest, as they will allow to see relations between diagnostic personal parameters and real professional success urgent medicare and medicine of catastrophes service workers in the process of professional activity implementation.

The conception of continual-hierarchical personality structure by O.Sannikova and axiological project of the professional and personal development of professional worker in sphere «man-man» by I.Hrytsyuk are connected with concrete methods and psychodiagnostic instruments that allow to form the model of empiric research of professional selection urgent medicare and medicine of catastrophes service workers.

As psychological features on emotionallyvolitional and motivational-valued levels changes less in the process of activity in cause of their rigidity and stability, than professional qualification, knowledge, ability and skill, they first of all are of interest during realization of professional selection of urgent medicare and medicine of catastrophes service workers.

Keywords: professionally important internalss, competenses, competence, supervision, interview, psychodiagnostic and biographic methods, assessment-center method.

\section{Удод Максим Александрович}

Аспирант Института психологии имени Г.С. Костюка НАПН Украинь, г. Киев (Украина)

\section{МЕТОДИКИ ОЦЕНКИ ПРОФЕССИОНАЛЬНО ВАЖНЫХ КАЧЕСТВ И КОМПЕТЕНЦИЙ РАБОТНИКОВ СЛУЖБЫ ЭКСТРЕННОЙ МЕДЕЦИНСКОЙ ПОМОЩИ И МЕДИЦИНЫ КАТАСТРОФ}

Аннотация. Установлено, что в практике психологии управления человеческими ресурсами представлено большое разнообразие методов оценки профессионально важных качеств и компетенций, а именно методы наблюдения, интервью, психодиагностические и биографические методы, метод ассессментцентра. Для оценки профессионально важных качеств и компетенций работников службы центра экстренной медицинской помощи и медицины катастроф (ЦЭМП и МК) целесообразно применять методы экспертной оценки, структурированного интервью и психодиагностические методы. Психодиагностические методы представляют особый научный интерес, поскольку их использование позволит увидеть связи между диагностическими параметрами и реальной успешностью работников службы ЦЭМП и МК в процессе выполнения ими профессиональной деятельности. Поскольку психологические характеристики человека на эмоционально-волевом и мотивационно- 
ценностном уровнях менее поддаются

изменениям в процессе деятельности, чем характеристики его квалификации, знания, умения и навыки, они в первую очередь представляют интерес при осуществлении профессионального отбора работников службы ЦЭМП и МК.

Ключевые слова: профессионально важные качества, компетенции, компетентность, наблюдение, интервью, психодиагностические и биографические методы, метод ассессмент-центра. 